\title{
Bonaventura's Anthropology
}

\author{
Farshad Aliyari ${ }^{1}$, Qorban Elmi ${ }^{2} \&$ Amirabbas Alizamani ${ }^{2}$ \\ ${ }^{1}$ Department of Theology, Branch of Philosophy of Religion and New Theological Issues, Isfahan (Khorasgan) \\ Branch, Islamic Azad University, Isfahan, Iran \\ ${ }^{2}$ Tehran University, Tehran, Iran \\ Correspondence: Qorban Elmi, Tehran University, Tehran, Iran. E-mail: gelmi@ut.ac.ir
}

Received: December 23, 2015 Accepted: January 15, 2016 Online Published: March 31, 2016

doi:10.5539/jpl.v9n2p9 URL: http://dx.doi.org/10.5539/jpl.v9n2p9

\begin{abstract}
The aim of this study is to explain Bonaventura's anthropology theory as one of the main issues in the philosophy of religion. This article examines this issue by referring to the works of Bonaventura as well as descriptions and interpretations written on this field using descriptive-analytic methods. Bonaventura knows human as God's image and unlike some of the Christian philosophers considers'matter'in addition to 'soul'anddoes not separate soul from body.Following Augustine, Bonaventura knows human soul as body image so that soul can affect and be affected. He properly accepted two types of self-knowledge, first, he believed that an inner queen exists in human existence possessing the ability to thinkand contemplate on its own and Second, alternate activities of thought about itself, which is due to resorting to internal contemplation. Bonaventura knowsthe fact of human as something through which he/she can communicate with God and accordingly believes that human as the image ofGod has the power of thoughts and authority; He has a standpoint of "from Him" and "to Him". The superior position which Bonaventura intended for human in the universe is that human is a microcosm. Because he/shewill reflect its creatormore than any other creature in the material world.Nevertheless, Buenaventura believes that human has collapsed and original sinhas disrupted the realm of the intellect, emotions and human actions; He also explores the realms of human existence such as soul, spirit and heart so about heart he suggests that if human heart becomes clean and pure existence, his/her existence and nature is God's Wisdom Book. He believes that human can reach the highest level of wisdombecause he/she is the God's word (promise). Bonaventura believes that the foundation of human relationship with God is romantic; He knows the truth of human in relation to absolute (God); and part of his thoughts in relation to the human is focused on perfect human and perfect man knows Jesus Christ and introduces him as the inner teacher all mankind.
\end{abstract}

Keywords: Anthropology, Bonaventura, Soul, Self-Knowledge, God's Image, Original Sin, God's Word (promise)

\section{Statement of the Problem}

Human is the only creature who has deep and unbreakable connection with God so thatparticular sanctity and dignity for humanis drawnin religious texts;This complex and polygon entity hasalways been favored by scholars, philosophers and mystics and everyone viewed, explored and examined him/her from his/herown perspective.Mystics and theologians had and still have views and perspectives related to human. Human that according to the religious lawof the great prophets takes over with incipient flow of the world in harmonyandwhose secret of happiness and wellbeing exist in practicingGod's commandments and religious law.Regarding the views toward human, different types of anthropology have formed throughout history including:Philosophical anthropology, mystical anthropology,scientific anthropology, religious anthropology, social anthropology.... Each of these anthropologies emphasize the particular aspect of humanwhose perception depends on definition and nature and quiddity of human from their perspective.Religious and mystical anthropologyis one of the deepest issues that arise in the field of religion and divine knowledge so that it deals with introducing human nature, his/her special place in the world of creationand his/her relationship with God.SaintBonaventura also considered the issue of anthropology and the bulk of her ideas are in relation to humanwhich will be described and expressed. 


\section{The Quiddity of Human}

Human mind has always figured with questions such as what type of a creature humanis. What are the most important human problems? What distinguishes him/her from other creatures? What are the apparent or hidden aspects of this creature? What's the truth and nature of human?Is soul the truthof human?Or her/his body?Thinkers, philosophers and mystics have tried to answer these questions with regard to the dimensions of human existence.In Christianity, the human is an image of Godand the grace of God; he/ sheis directed toward a specific endand he/ she obeys and operates God and has a causal impact that has been influenced by the ideas of Plato.Another point is that some believe that the Christian God is spirit, and human can be linked only through the Spirit with God and God must be worshipped in the spirit and truth. Therefore, it is expected that based on the teachings of Christian philosophers and itself,human effort should be focused entirely on the spiritual aspect or her/his soul. But thinkers such as Bonaventura and Thomas Aquinas, who also considered the material (body) in addition to soul, theyrespected their bodies and never intended to tear soul and body apart.This opinion is taken from the Bible, so that the gospel promise the salvation to include not only the souls, but also the people namely salvation of each individual human beings, with their flesh, with their body, with their all the buildings limbs, so that if they were free of which, nothing remained except a phantom of them even unimaginable to themselves"(Gilson, 1987, p. 283). Augustine also believed that human wascomposed of soul and body so that he states: "the soul that possessed the body, determining a person and not two people."(Copleston, 2011, vol. 2, p. 100). Bonaventure is a follower of Saint Augustine believing that human soul is facing the body. "But although Bonaventura accepts the Aristotelian definition of the soul as the image of the body, his general tendency naturally is Platonic and Augustinian, to the extent that emphasizes human soul as a spiritual substance who is composed of spiritual figure and material.It is not enough to say that there are in the soul, a combination of "what is" and "what it is because", because the soul can affect and be affected, move and be moved and this is the evidence of the presence of "substance", principle of passivity and variability, however this substance is devoidof the protraction and corruption because the substance is spiritual, not physical.

It may seem that it contradicts with the accepted simplicity of the human soul. But Bonaventura pointed that "simplicity has several meanings and degrees. Thus,simplicity may refer to the lack of quantified implementation. The soul compared to physical creatures is simple and profits from this simplicity orit may refer to its components hence soul cannotprofit from this simplicity.But the main point is that although thesoul is body's figure and its stimulus, it is much more thanit and can survive by its own andwould have existed.Even though existence has somehow passive and changeable nature but it should has spiritual nature also. So material - formal composition theory of the human soulis designed to provide the ability to survive outside the body (same, p.363). Bonaventura believes that soul needs external matter to carry out its activities. As it also has a life of its own, it has internal matter. Bonaventura got help from Aristotle to prove the human soul is composed of matter and body figure. Aristotle believed that there areacceptable origin and matter in each object, so there isan intellect inthe soul that all things are identified by it and there is an intellect specifying them. According to this, we can define man as anintellectual animal. Bonaventura states another reason for body and soul figurecombination.That is, the soul is happy or sad according to a development of the inner change. Anything affected by paradoxbased on the inner change is just one and is an essence also that existsby its own. The soul is something of this kind and as it composed of matter and figurethenthe soul is a combination of both.

\section{Theology}

Medieval philosophers always focused on the words of Socrates that stated" know thyself". As Saint Bernard in this regard stated "if wisdom is for man own and drink water first from his own wells, he can begin theology from here.If yourregard turns back from yourself, you require turning it over yourself to be blessed. You are both the beginning and performance for own sake (Gilson, 1987, p.348). Self-scrutiny theory of Bonaventura is clear and simple. He accepted two types of self-scrutinies that almost are consistent with the theory of Augustine. Firstly, he believes that there is self-awareness that can think.Second, alternative thought activitiesare due to turning to the internal note. It seems that Bonaventura did not confirm trans-knowledge of self-knowledge.Instead, he claimed that soul was aware of itself from first, in the other words soul are always self-present. Bonaventura often avoidsthe word of "habit" and prefers to express that soul has the ability to know itself. The soul inherently can think about itself readily. This ability may reveal the advantage of self-consciousness or self-knowledge as a part of its essence. Bonaventura believes that cognition is dependent on self-knowledge (scarpellicory, 2013, p.34). Bonaventura suggests thoughtful activities of soul about itself are not random. Actually when soul or spirit thinks about itself doit by essence because it existed before itself and did not need to sense or perceivefigure from the outside. The anthropological function of Bonaventura includes self- knowledge, rationality and non-material beings (ibid, p. 35). Bonaventura has applied traditional sources include: soul as God image and self-knowledge 
within God essence. He argues that soul is self-consciousness in term of presence and the essence and the soul due to rational power know itself. So Bonaventura applied rational principle for knowing a prior and essential issue. Bonaventura confirms that the human soul is a spiritual essence so that is formed from spiritual figure and spiritual matter. Bonaventura supposes the soula simple essence but he believes that simplicity has several degrees and meanings. Bonaventura supposes self-knowledge as the light of the rational principles so the figurewhich is a grace of Godcreating light have been delivered to man and have created highest level of soul degree within inside. Medieval philosophers include Bonaventura invites man to recognize secrets related to the soul. They believe that man can know himself if he figure out soul secrets. Bonaventura claims that man can find that he relates to the truth of God and truth in thematerial if he considers truth within himself. Thesoul as intermediate between the two extremes tend to God by it superior section and tend to thing by its knowledge section. It perceives relative certainty with its subordinate and perceives absolute certainty by its superior(Gilson, 2010, p.476). Accordingly, the man should attend to his reality include soul, power and various talents to understand soul exactly and reach self-awareness step.Pascal in this regard states that " recognition of one's self means that the man realizeshis limit and specify his order and distinguish what the superior or inferior he accept or have in himself and what is completed, treatment could be going down, an act that should or should not he does, they all must be understood. In this case, the person can know himself (Gilson, 1987, $\mathrm{p} 350-349)$. Thus according to Bonaventura human reality does not consist of his material, but his reality consist of something that due to it can communicate with God and talk to him. Thereforethe human deserves to recognize his talent, features and capabilities exactly and certainly someone who knows himself knows others better.

\section{The Human, God Figure}

Bonaventura believes that the manhas created likeGod figure. The man is similar to God not in term of physical aspect but also in term of spiritual aspect because the spirit andthe intellect arethe most important parts of the human. The greatness of the man is due to his similarity with God in the figure and has authority so that he naturally do everything according to his desires and by his reason know the nature then overcome to it( Gilson, 1987, p.350). Bonaventura thinksGodfigure in human due to directs intellectual and voluntary relation is an advantage and important feature. Of course "God image should not suppose in this sense that human-like God knowsit but he aware that he has created as figure in which have guard in his soul that is because of his likeness with God and is a means for connection to God(the same p.346). The bible says: "let us make man in our figure and like us"(Genesis/1:26). Accordingly Bonaventura in his work suggests that man as God's image have power and intellect. Thus he is superiorto other creatures, so that man because his likeness with God tends to God immediately. He states in this regards "other creatures created to serve man as far as love of the man increases with looking them and the man eager to pray him in his heart (Quinn, 1973, p.137). Bonaventura argues that soul due to achieve happiness includes supreme goodness means God created like God. In another word, man's word because of having the intellect and divine wisdom links the man to God. "The eyesightby whichGod see me is the same eyesight that we perceive God by it since me and God are one. (Austin, 2009, p.332). The soul has been createdsimilar toGod figure and has been attended to him arbitrary. Accordingly, the man is the noblest creature that God has created. Bonaventura suggests that the human soul as God image deserves to equip itself by three virtues: refinement, illumination, perfection that God image is modified within the soul by these three virtues. Bonaventura recommends that soul should believe to Jesus Christ absolutely since he is truth path and man can achieve recognition through him (Bonaventura, 1978. p.98). "The first indication of God'sfigure and his instance is the totality. We state in explaining the totality that Godfigure does not means a transverse order that joined to human nature, but is as human nature and its assessment mode.GergorisNosaaee states that all human beings created without any privilege in figure an instance. And this idea also exists in Tomas Akinas and Bonaventura and DonesScotes works (Gilson, 1987, p.343).

Bonaventura followed Agostin supposes divine image as the connection of wisdom with God. The man as a drop that is a little image of its origin comes back to sea and is united with it thus drop convert to sea own. The human soulcomes to union with God and being one with him if it passes spiritual journey. So he doessomethings that God want, actually he becomesGod mirror and Bonaventura offers this matter in third part of soul travel toward God, and he argues that the soul can become God mirror by three powers of memory, knowledge and love)(Bonaventure,1978. p. 103). Tomas Aquinas also has the same idea: "There isan image of Godwithin the soul because itjourney toward God;or because its nature allows it totravel toward god" (Gilson, 1978, p.346). Bonaventura viewpoint is based on "from him" and "toward him" and suggests that all things result fromthe same thingand will return to it. That is the human soul return to God and becomes survive. Christian philosophers believe that "self-identity is something other than the image of what was dropped from meaning to the material or is not a corruptible figure that has complex object. The soul is the eternal spiritual essence that has imperishable 
characters (Gilson, 1987, p.359).

Bonaventura according to illuminatedview assumes that divine light within the human leadit to knowledge and wisdom. This light shows that human has created similar toGod. The soul has spiritual meaning proving real and original essence since the soul results from divine lights. Ones whocan recognize the soul and the human being, he also can recognizeGod. The soul has created somehow can find happiness. The supreme goodness which is God own is available to him. Therefore, he is able to accept God in his inside and so the man's image should be similar toGod. But if this soul is mortal he cannot be like God.Thus Bonaventura through it concludes that man soul like God image is immortal. In addition, Bonaventura believes that the soul has so muchglory that makes him like God. Therefore this soul that is God's imageaccounts his happiness in union with God (Copleston, 1950, p.280).

Bonaventura believes trinity in related to which the human is God's image and this image results from him and is like him. He believes that this image reflects the triple feature of God. This creature -the human being - has memory, intellect and authority.In the other word the thought, knowledge and love according to Bonaventura, thought is like Father own and science is like Son own and love is a relation that connects both together.

\section{The Reality of Man}

The human has dual nature, or in other words, he is a two-dimensional creature that one of his dimensions is divine and other is material. Bonaventura received his material composition theory from his master, Alexander O' Hils who believes all things are composed of matter and figure, of course "Original matter for him is the word more generally not means which is against the soul. The matter has its origin and it is not spiritual, nor physical, and thus by itself it is inevitable to be physically and spiritually (Kapelston, 2011, second volume, p.353). According to Bonaventura, human truth composes of the soul because soul as mentioned is God's image. The soul results from God, so it is soft and glowing; according to Bonaventura human soul have intellectual and sensory faculties and this is soul which is human figure. " The soul as is figure of all human body, it exists in throughout the body because it is simple. So its presence is partly, some here and some there since it is adequate stimulus origin and does not have special status and there is not at a certain point in the present" (same, p.363). Actually the human is the talking soul who is a place for thinking because thinking is one of the intellectual forces that reality of human being depended to it. The authority, responsibility, and many other capabilities result from the intellectual force. The human due to intellect and thought can be perfect as if he does not have this power he does not differ with the animal. We know that thought results from the soul and soul come from Godand places in human identity and due to it the human stands superior to other creatures." every human at first is a person as well as being individual, he has other traits since a person when calls the person that consider personal essence especially in term of degree of virtue and honor. The animals are the individuals but not the persons. Always any creature is called person due to his highest degree of honor.One of its indications it that when we want to magnify someone always describe him in term of the superior competence we can observe in him. But in that case we find the highest level of dignity is his intellect.For the definition of person, it must be said that there is something in each person that is wise (Gilson, 1987, p.342). Bonaventura in the analysis was been very successful that is one the best interpreters of originality in the world of Christianity. As noted before, Bonaventura supposesintellect as the human truth. The man is composed of body and the soulsince this is the soul that can be released from material dependence and in connected to the active intellect. Bonaventura says that greatness of human nature is indebted to the dignity of the human soul. "The dominant position that Bonaventura considered for human in-universe is that the human is a microcosm. Because he more than any other creature in the material world will show his creator. Rather, the image of God reflects in himself. Wise soul manifests itself not only in God, but God is manifested through the unity with the body. AsGod governs on the great world, the soul is also governing the body. Therefore, the excellent conditionswhichthe human obtained in the world result from his wise soul (Quinn,1973, p.138).

Muslim mystics also suppose man is a microcosm so that the man is the microcosm in term of the figure, but in term of truth and meaning is the greater world. Apparently, the man situates in the last stage of creation, but in term of meaning actually is its initial creation because the purpose of creation is the emergence of the divine attribute and actions. And human is as a manifestation of the emerging. The human beings are in their nature both good and evil. So the human has both evil feature and angel feature. The good aspect of him refers to his soul and evil aspect refers to his nature and passion.

\section{The Man and His Original Sin}

Christians suppose that the Satan is the leader of insubordinate angelswho come as a snake to Eve to tempt her. The Lord allowed him to do it but forced him to come as snake since his cunning covered and all future human kind know how Satan with trick could tempt Adam and Eve carefully. The Satan attacked to highest level of human- his rationality. He did itby inducing doubt within human heart regardingperformance of God's commands. He started 
his duty with asking the question of Eve about the prohibition of eating from the tree and told her that this prohibition is arbitrary and it does not have intrinsic value. The descended angel promisingEve she can perceive the wisdom of goodness and badness and will become like God, sosome kind of sensual desire is created within her Actually, Satan exciting Eve to use his authority deceived her to disobedient God. The man abused his authority with his original sin. The human as other creatures was changing, moving as well as being devoted and free. Thus, he had the power to do wrong and did it. His fault was not that he wants something which is bad by itself because imaging such a thing involves a contradiction, but his deed means leaving superior casethatrequires giving up better to get good. The man was created for God but he selected himself instead God and with doing it he involved his evilness in the world.Or to be more precise, if angelsdid not it before, he did. This badness has something that was special to him and this trait could be a differentiating factor from moral vice in Greece philosophy. The wrong which Adam was convicted with this disrupting the order was not only disrupting natural intellectual discipline in oneself and bringing down humanity order or was not only according to Plato at some stories in his epistles.The man not onlylost his density with an error, but also he disturbed the divine order and represented distress and tragic effects of revolt of a creature against an absolute entity. So the moral and spiritual evilness in Christian philosophy has special name and this name can be generated to other sins resultedfrom first error and it isthe sin" (Gilson, 1987, pp 194-195).

Bonaventura believes that Eve was unable to read inward book that had been opened to her and was readable for correct judgement of intellect. She engaged her mind in external book and apparent goodness. Bonaventura believes that soul has fallen and original sin disrupted intellectual structure and human deed.He supposes that the man results from two things: first extreme love to female and second the selfishness due to transient pleasure and joy. Bonaventura integrates Anselm's view based on that original sin results from justice between man and God and with Augustine's view according this lust results from original sin together. But there are some problems in transferring this sin to others. This sin cannot be transmitted through soul since the soul has been created directly by God. Bonaventura triesto solve the problem of the transmission of original sinbe expressing that this sin was brought in through body and by creating lust in brought in the oppositeof soul. He believed that sin had been entered this word by the will of man not God will. So man is imperfect in any situation and does not have any possibility. If he can get this possibility he will be more perfect. Bonaventura believes that man was created based on this fact and being imperfect naturally means that he was created from nothing. However ability to choose freely enables him to choice the goal. The great secret of evilness is hidden in this point since freely choice requires to choice a goal opposite of goodness(Gullen, 2006, p.135).

Accordingly, moral evilness due to freedom of human is performed. Theman has destroyed himself and offered his freedom to lust and has fallen. In the words of Augustine "The sin was created in the world by Adam and death came with it"(Gilson, 1987, p196). Now man how can be released form the sin and what is salvation way? Bonaventura considers salvation way in turning back to God. In this way, man needs help. A perfect man should show him eternal truth and this perfect man is Christ. Christ comes to restore man's sin. Sothe human being will be save through Jesus Christ but he will be saved when has faith, hope, and love (Bonaventura, 1987. p.104). If human freely follow divine rules, it is ok; but if he freely avoid them, it is inappropriate.

\section{The Spheres of the Human Existence}

The materialists believe that truth of the human being is his body and represent that the humanscreated due to molecular interactions and live a period in this world and then they will be lost. But in contrast, the theologians and the believerssuggest that man is a creature composed of body and soul and his truth make the soul and spirit. Saint Bonaventura who believes to divine religion supposes that the human being is composed of matter and figure.He figure on his own entity dimensions and states many subject in this regard that here it is referred briefly.

\subsection{The Soul}

In Christian theology, there are three perspectivesrelated to the soul, firstly it is believed that soul entity is superior to the body (pre-existentialism). This idea is near to Plato's view who believed that our soul has been existed before our bodies in the world. The second view maintains the coincidence of origination of the soul and the body(Traducianism). Third point of view attaches to the creation of self-independence of soul (creationism) so that the creation of body does not relate to creation of soul. Bonaventura states regarding origin of the soul:" if we want to discuss about origin of the soul we should correct two errors first. As the soul is spiritual then it does not wretch because of linkingwith body. While the soul is essence, it is impossible that the view of EbnRoshdian about being a single soul for all the manbe accepted. As we mentioned the errors and solved them, then this question is mentioned that when the soul has been created? (Pegis, 1983, p.49).

Bonaventura argues that the soul has been created in form ofGod and like him. He assumes the soul as a body 
figure. Bonaventura believes that the Lord has created the human soul at the same time with the body or maybe following it and the human has not created himself. He argues that the human soul is a substance which exists by itself so it has matter and figure. Substance in the human soul is a spiritual substance that is created with a figure. As this figure is also spiritual, the soul is absolute living and all soul forces with following intellect are under the command of superior part of mind. "The superior part of mind thinks about what belongs to its realms and decides about them. Therefore superior part of intellect brings inferior and humble powers of human soul under its subject (Quinn, 1973, p.200). Bonaventura states about the soul collapse in his book, soul travel, and emphasizes that the God is close to our soul but a few persons understand it within inside, it is because the soul is infected by sin. The desire causes the soul to be contaminated in such a way that the soul cannot image God in his inside. Bonaventura believes that the spiritual powers of human created based on trinity structure which includes: memory, intellect and will. For the pure souls self-realization is the same.

\subsection{The Spirit}

Bonaventura calls spirit the superior part of soul more close to God and argues that this is soul which makes immortality and incorruptibility. He believes that because the soul is spiritual so it is free from any physical substance. The soul is close to God "The soul as life realm links existence power with existence meaning. The soul can be defined as activity of power and meaning united with each other. In range of our experience, it exists just in human and all their dimensions of his life. The man in his experience as the human being knows that the spirit as realm of life determines his nature(Tillich, 2010, vol.3, p.2).

It seems Bonaventura in regarding to spirit has Trinitarian thought so that the spirit is a lasting love which reflects Father perfectly in Son. According to Bonaventura the soul is as connecting point of love, and according his perception, the soul is a gift from God. In Bonaventura thinking system, soul unites Son with Father (Dourley, 1975, p.126). In Christian theology it is believed that there is divine spirit in human soul and has activity in it. Of course this means that human soul surpasses itself and spiritual presence completely fills the human spirit. The spiritual presence does not eliminate intellectual structure of the human spirit, but doing activity which the spirit can do it. Divine spirit attends in Jesus as Christ without distortion so that according to Christian theology God existed in Jesus as the Christ. In this regard Bonaventura suggests that man should deliver himself to Christ and pass some steps to be united with Christ. When he is united with Jesus Christ find new existence and enables the soul to reach superior perfect and happiness and love is very important here. It can be united with divine spirit by love results from submission and reach survival order. "One of the obvious Platonic thinking of Bonaventura can be seen in Tenoir's theory. He and Augustine believed that immutable concepts such as justice and beauty are perceived by the five senses of human, it means that they cannot be perceived by observation, reading or hearing, but these concepts are perceived directly by human soul due to eternal entities like beauty and justice" (Lynn, 2011, p .203). Therefore according to Bonaventura human soul is a factor for recognizing, understanding and insight. This soul also constructs divine gift and human truth that through it man can ascent to God and have a divine and romantic life. Bonaventura believes that "God must be found in the human spirit". The mind due to divine light is aware ofeternal truth and immutability. The presence of God is so immediate and real that it actually understand the human soul (ibid, 206). It can be said that the human soul is a manifestation of divine nature sosoul can know its nature and comes toward him. In the other word, the human soul is in an image and shadow of the divine spirit.

\subsection{Heart or Heart}

Heart is manifestation of God. It is heart which can accept the God, so mystics and philosophers have paid special attention to the heart and have always recommended that heart should avoid any obscenity, filth and attachment to worldly things. The heart is place of God not strangers. Bonaventura considers a special place for hear in his book," the soul journey toward God", so that in one stage he talks about purification of the soul and heart. He believes that in illumination step which divine light shines on the heart, the soul does not commit sin and evil. The person should act somehow to light be emitted to his heart and deserve grace and mercy of God. Bonaventura argues that the man can only ascend to perfection through the heart since heart performance is much better than intellect. Therefore the man perceives superior beauty, the God(Bonaventura, 1987, p.102). He states in his paper" soul journey toward God" that it is better human equipped with three virtues include refinement, illumination and perfection. These three virtues certainly result from heart performance. The man can believe to Jesus Christ when his heart accepts him and his faith is certain and Bonaventura states this issue in various works. We due to the light in our heart and by the grace of Holy Spirit can ascend to happiness and prosperity." if your heart is pure, your nature and identity will be as a book of divine wisdom" (Trasdale, 1999, p.193). Such a wisely words of Bonaventura show that if human purifies his heart from any sin, divine light will shine on it so that wisdom light and attribute of the God will be manifested. Such a heart is indication of virtue, wisdom, goodness and every good will and certainly God loves someone who have pure hear more and the owner of such a heart is near the God. So it is better the man tries to 
purify and filter inside to get attention and grace of the God.

\section{The Man and the God Word}

According to Bonaventura the soul is united with word and therefore it finds more similarity to God. He believes that Christ has superiority and excellence perfection since according his view the man does not have an infected nature. Bonaventura considers Christ as the word. At the beginning of the Gosper, Johannes says:" the word existed and was with God" (Johannes/1:1). Certain role of word in human wisdom is as a principle indicating existence and intelligibility. This word come from God and has been manifested in Jesus Christ who is omniscient(Scarpelly Cory, 2013, p.72). Bonaventura believes that the human being can find highest level of wisdom through the divine word. As word has been manifested in Jesus Christ so he is omniscient who has emerged on earth and he is perfect man. So the man should consider Christ as his model in life to pass perfection steps. "The word shine human mind, the word which is luminous for every man who is born. Jesus Christ is a spiritual teacher and no truth can be known except through him, not through his speech in the same way as we speak... He exists totally with every soul and enlightens our dark thoughts by his most clear thoughts. We have no vision of the Godword and although this light exist within us, it is invisible and unattainable"(Copleston, 2011, vol.2, p.374).

In Christian theology, it is expressed that God's word relates to divine knowledge directly so that "Bonaventura considers science as divine truth. Actually, he suggested that divine knowledge is based on accepting divine's word and for this reason from first every action which Christ did for help others expresses the God own forever. In addition each of these effects supposes scientific knowledge. So scientific knowledge involved in such a science expressesGod due to it in his word"(Gilson, 1987, p.26). In Christian theology, it is stated that any impact of badness is arose in opposition to the word of God and goodness results from divine word. "Just the Word is God indication, the humans were created just as God figure" (same ibid, p.444). Accordingly,how man is more similar to God, he can realize special nature more. It is better that the man become perfect figure of God and God's love manifest in him. This lovely bond between human and God certainly is realized by the word and due to the word. Accordingly, Bonaventura suggests that human should be united with God and when he reaches united step, a single soul creates. This is holy love which is absolute pure and certainly for human to being perfect requires being ready for love to God.

\section{Human and Divine Love}

Christian mystics believe that human should live with love instead just talk about it. The human enthusiasms never give out but God callsthemto himself every moment and this is mutual love. The issue of love is cooperation with God. "Love is moving every creature toward another creature to over-come separation. Love in regard of realm of consciousness involves arbitrary element means will to alliance. Such a will is inherent in any romantic relationship, because the wall of separation cannot be torn down without a will. Emotional element will not be so strong if,freedom and realization do not combine(Tilich, 2010, vol.3, p.163). The issue of love in Christian theology is parallel with knowledge so that the soul can perceive truth through intellect and can get goodness through heart. "The reason of our love to God is God own because he is who creates us with love, but if it is right we should go beyond it since love is demand to get its desire. So if we cannot wishGod without him so without God we do not able to look for him. So God want human beings have God due to compassion that make human seeking to God. It is possible to seek him, but overtaking him is impossible, none can seek him unless he has found him before. This word which is resonated in famous book of Pascal represents special meaning of love in Christian's though (Gilson, 1987, p.429).

Bonaventura mystical divine approach considers love as the base of relation of God with human so that he creates a dialogue between human spirit and divine love that results in unity with God and find a faithful living and belief to God, and through it finds knowledge which is maximum illumination. Bonaventura states that we should unit with God of love and in spiritual theology love can reach to such a step as remembrance and being with God(Hammond 2014, p.399). God's love is endless and non-determination and involves all things. The love of God is the love of everything and this love represents every things, the man can find knowledge and awareness completely through it. ones who is full of divine love see every things good so that in light of this love considers himself humble and drown in the honor of God and in such a situation he never infected by sin. Bonaventura in his life as a saint and theologian always tried to live based on the love of God. "Love of God is the center of Bonaventura thinking. Bonaventura in his works tried to represent this love by mystical- spiritual reason. The aim of human beings in worldly life is finding eternal happiness and uniting with God. Everyone who is aware or unaware of this aim but does not perceive spiritual reflection certainly has wrong will and suffers from intellectual lost. The desire for happiness is in human nature but he should be perfect in regard to theoretical reflection to find 
happiness. The man should have piety and avoid worldly asceticism values. The role of theoretical thoughts in intellectual system of Bonaventura is so that happiness, enjoyment and delight are supreme goodness and because of being supreme goodness it should find supreme to take advantage. Ascending to supreme goodness is not possible through body but this ascending is performed by heart. The heart ascending involves not only intellectual ascending but also only involves feeling and love. Of course it should be noted also that Bonaventura considers unity with God and getting happiness through love and will instead wisdom and intellect. In the other words, theoretical reflections is the complements of spiritual journey to the God(Partriarch, 1392, pp.359-358). Bonaventura suggests that God's love is unique and eternal and human always should increase this love inward and by faith in God and hope for prosper journey toward God and always love everything just for God. Asactual love is love of God so the only purpose is it and always this romantic relationship between man and God is worthy to be strong.

\section{Relation of Man with God}

Bonaventura in the second chapter of his book, the soul journey toward God, suggests that perceiving God through material world is first step of human ascending to God. The human has the ability of perceiving God in this world.In the other words, God in this world is based on human choice and God helps man to perceive it since God for human mind is as a light. He writes in his book, journey to God: "ones who want ascend to God firstly should avoid of sin which spoiled our nature. He should use mentioned natural power: get regenerative by grace, gets purifier justice by good life get wisdom illumination by thinking, get complete ruling by contemplations. While no one except by the grace cannot find wisdom and knowledge, so no one cannot find wisdom and contemplations without reflection and thinking, holy life and worship (Lynn, 2011, p.209). The relationship between God and man is mutual and this is the same mystical theology approach and this relationship is based on the similarity of God and man.

"According to Bonaventura everything in this word is an indication of existing God and every creature as a trace, as an image and as a similarity with God relates to God and according to Bonaventura there is a principle that leads to highest step(Scarppelli Cory, 2013, p.71). The amount of closeness between God and man depends on width and depth of his knowledge - and this closeness is different in each man based on likeness toGod granted his by divine grace." if someone is eager in ascending soul to God, then his thought become a focus for concrete man"(Caplestonm, 1987, vol.2, p.319). Bonaventura in his last step of soul journey to God with purpose of thinking about God asks man to demand some issues in his life, somethings like: grace, passion, crying, praying, Jesus, God, surprise, illumination and flame which is all burning and leads human to God by burning emotions(Lynn, 2011).

Each of these can be a way for relationship between the man and God. Christian philosophers and mystics believe that God is our motivation in such a way that he is the same lover and creator of love so that the love of man to God is a grace from God.

So Bonaventura suggests the man to demand grace, this means that he should connect to glory source and do not involve in fracas of schools. The human deserve takes passion since he seeks toward love which starts from God and will turn back to him. In this way he should request from God, pray and demand. Best way to do it is resorting to perfect man as Jesus Christ. If we drown in the teachings he will help us.He takes our hand and lead to God, since Jesus in a connection point between man and God and the man is better to seek wonder.It means wandering and in the terms of mystics is something which enters mystics' heart when thinking and attendance so that wander is like happiness and the mystic asksGod to increase his wonder. Certainly Bonaventura also has the same view and approach. In this journey the man should perceive divine light through which finds so much insight and knowledge that always burn in light of divine love and he will never neglect even a moment and become united with God that is peak of romantic relationship between man and God.

\section{Conclusion}

Bonaventura as Agustin emphasizes that the human being is a spiritual essence composed of spiritual figure and spiritual matter. He believes that the soul also can effect on others and also be affected. Bonaventura believes that soul needs exterior material and as it has also life and inner matter, he resort to Aristotle to prove that the man is composed of matter. Bonaventura as Socrates emphasizesonthe self-conscious so that his self-knowledge theory is clear and simple. Bonaventura idea is consistent with Agustin theory.He believes that there is an inner spirit within human that is able to think. In addition,alternative activities of thought due to turning to attention and accuracy are inward. Bonaventura claims that the soulknowsitself and can recognizeit. Bonaventura applied traditional sources for self-knowledge,the topics such as the soul as god's image and self-knowledge in god. He emphasizes that self-knowledge realizes in light of rational principle so that it realized due to divine light and 
supreme degree has created within human. The man should attend to the reality of the soul and power and various talents to understand the soul exactly and reach self-knowledge step. Bonaventura believes that the human has created similar to god and god's image within human is an important advantage for direct rational and optional relation with god. The human can think and has authority so that human intellect is a light of sacred essence god and tend to unity with god.

Bonaventura believes "for him" and "to him" view and thinks that everything results from a single nature and return to it. Because of this, the human soul returns to god and survive. Bonaventura in regard of being human as god image has Trinitarian perspective. The image for him is the same as image owner and believes that this image reflects Trinitarian trait of god. Bonaventura states that the soul makes the man's reality since the soul as mentioned results from god. Therefore it is soft and glowing. He believes that greatness of human essence is due to the honor of the rational soul. The superior situation which Bonaventura has considered is that the human is posterior essence since the soul more than other creatures represents its creator in material world.In the other words the soul realizes god's image within inward. Bonaventura believes that the human has fall down and origin sin has disrupted intellect, feelings and deeds of human. He suggests that the sin results from two things: extreme love to female and selfish due to pleasure and fleeting pleasures. Bonaventura tries to find a solution for transmission of origin sin problem.He suggests that this origin sin will be against him from the soul and through the body and with the creation of lust in the souls. Accordingly, the human is imperfect naturally. However the ability of arbitrary choice enables him to choice the goal other than god and the great secret is it. The man needs help in this step and a perfect man should show the eternal truth and this perfect man is Jesus Christ. Christ comes to rebuilt sin of human. The man will save through Jesus Christ justwho has faith, hope and love.One of the human existence aspects is the soul. Bonaventura believes that god is close to our soul but just a few understand it within inward. Bonaventura in regard of soul has Trinitarian thought and believes that the soul is lasting love that reflects the Father within Son. Bonaventura considers a special situation for heart in his book" the soul journey to god".He believes that the divine light will shine heart when human does not confirm sin. The man should decorate himself by three virtue include purification, illumination and perfection. Bonaventura believes that the man due to divine word can find supreme degree and divine word has realized in Jesus Christ so he is omniscient that has emerged in earth and is a model of perfect man. Bonaventura knows the truth of human existence linked with submission to god.

\section{References}

Charles, C. F. (2011). Thehistory of philosophy, medieval philosophy of Agustin to Scotus, translated by EbrahimDadkhah, second edition, Tehran: Scientific and Cultural Publishing Company.

Gilson, A. (2010). Christian Philosophy in the Middle Ages, translated by Reza GandomiNasrAbadi, first edition, Qom, religions publication.

Gilson, A. (2010). Spirit of medieval philosophy, translated be A.Davoodi, Tehran: Scientific and Cultural Publishing Company.

Ilkhani, M. (2013). History of Philosophy in the Middle-Ages and Renaissance (6th ed.). Tehran: The study and Humanities Textbooks in Universities(Samt), Center for Research and Human Development.

Stin, V. T. (2009). Mysticism and philosophy, translated by Baha al-din Khoramshahi (7th ed.). Tehran: Sorush.

Tilich, P. (2010). Systematic Theology translated by Hussein Noroozi (2nd ed.). Tehran, Hekmatinstiture Publication.

Tony, L. (2011). history of Christian thought. translated by Robert Esri (4th ed.). Tehran, FarzanRoozpulication.

\section{Copyrights}

Copyright for this article is retained by the author(s), with first publication rights granted to the journal.

This is an open-access article distributed under the terms and conditions of the Creative Commons Attribution license (http://creativecommons.org/licenses/by/3.0/). 